\title{
PENGARUH MOTIVASI INTERNAL DAN EKSTERNAL TERHADAP KINERJA KADER DALAM PROGRAM GEBRAK ( GERAKAN BERSAMA AMANKAN KEHAMILAN DAN PERSALINAN) DI WILAYAH PUSKESMAS BLABAK KABUPATEN KEDIRI
}

\author{
Triatmi Andri Yanuarini, M.Keb, Reni Triwahyuningsih SSiT, M.Kes. \\ Poltekkes Kemenkes Malang Prodi Kebidanan Kediri \\ Email: ytriatmiandri@yahoo.co.id
}

\begin{abstract}
High risk pregnancy is a condition where the condition of pregnant women can cause the fetus not grow in a healthy, even death in the mother and fetus. Based on data from Kediri District Health Office in 2014 amounted to 28187 pregnant women, while the highrisk pregnant women amounted to 5637 people (20\%). Number of high risk pregnant women most at Puskesmas Blabak number of 249 people with a total cadre 110 people. Scope K1 96.2\% (100\%), K4 coverage 92\% (95\%), high-risk detection by the public $13.77 \%$ (20\%), Bumil Risti handled $18.7 \%$ of health workers (20\%), obstetric complications which handled $87 \%$ (80\%), Assisted by health workers health facility $93 \%$ (95\%). Rewards and motivation to the Posyandu cadres is very important, especially cadres escort high-risk pregnant women. In the course of the RBM awards are expected to further spur the cadres to participate in social work in order to press AKI, so that cadres can increase each year. The design used in this study is a survey research. Judging from the nature of this survey is a survey that is explanotory survey to test the truth of a hypothesis to explain the causal relationship between variables. Data collected by cross sectional namely data collection throughout the study subjects were collected directly from the respondents through kuesioner.Analisa data in this study using the program, namely Smart PLS structural equation modeling with a relatively small sample size and not membuhkan multivariate normal assumption. The results of the study are not any effect on the performance of internal motivation of cadres in the RBM program. No external motivation influence on the performance of cadres in the RBM program. External motivation has the greatest influence on the performance of cadres in the RBM program. From the results of this study are expected Department of Health and the village is expected to provide additional incentives for cadres accompanying high risk pregnant mothers
\end{abstract}

Keywords: Motivation, cadres

\section{PENDAHULUAN}

Berdasarkan SDKI 2007, Angka kematian ibu (AKI) sebesar 228/100.000 Kelahiran Hidup $(\mathrm{KH})$ dan angka kematian bayi (AKB) sebesar 34/1000 Kelahiran Hidup (KH). SDKI tahun 2012 menunjukkan peningkatan AKI menjadi 359/100.000 KH dan AKB 69/1000 KH. Penyebab langsung kematian ibu adalah perdarahan (39\%), eklamsia (20\%), infeksi (7\%) dan lain-lain (33\%). Menurut hasil penelitian Untuk menurunkan angka kematian ibu secara bermakna maka deteksi dini dan penanganan ibu hamil berisiko perlu lebih ditingkatkan terutama di fasilitas pelayanan KIA. Untuk itu diperlukan deteksi dini oleh tenaga kesehatan dan masyarakat tentang adanya faktor risiko dan komplikasi, pendampingan serta penanganan yang adekuat sedini mungkin.

Kehamilan resiko tinggi merupakan suatu keadaan dimana kondisi ibu hamil 
yang bisa menyebabkan janin yang dikandungnya tidak dapat tumbuh dengan sehat, bahkan dapat menimbulkan kematian pada ibu dan janin. Ada juga yang mengartikan bahwasannya, kehamilan resiko tinggi adalah suatu proses kehamilan yang kehamilannya mempunyai resiko lebih tinggi dan lebih besar dari normal umumnya kehamilan (baik itu bagi sang ibu maupun sang bayinya) dengan adanya resiko terjadinya penyakit atau kematian sebelum atau pun sesudah proses persalinanya kelak.

Kehamilan risiko tinggi dapat dideteksi apabila ibu hamil melakukan pemeriksaan Ante Natal Care (ANC) secara rutin. Ibu hamil sekurangkurangnya menerima pemeriksaan hamil empat kali sesuai standar dengan distribusi satu kali pada trimester satu, satu kali pada trimester dua, dan dua kali pada trimester tiga. Termasuk di dalam pelayananan ini adalah deteksi tanda bahaya/risiko tinggi sedini mungkin, serta pemberian informasi tentang upaya menjaga kehamilan dan mempersiapkan persalinan agar persalinan berjalan dengan baik. Hal ini dilakukan bidan untuk menilai apakah perkembangan ibu dan janin berlangsung normal. Bidan juga harus mengenal kehamilan risiko tinggi/kelainan, bila ditemukan kelainan bidan harus mampu mengambil tindakan yang diperlukan dan merujuk untuk tindakan selanjutnya. Selain bidan, kader sangat berperan penting dalam upya deteksi dini ibu hamil resiko tinggi dimasyarakat (Adriaansz G, 2005).

Salah satu terobosan untuk menurunkan AKI melalui program pendampingan ibu hamil yakni memberikan pendampingan, motivasi dan menggerakkan ibu hamil ibu hamil untuk rajin memeriksakan kesehatannyaa selama masa kehamilan sampai masa nifas. Propinsi Jawa Timur pada tahun 2013 memulai program ini dengan menerjunkan 400 kader PKK untuk mendampingi 400 bumil yang tersebar di delapan kabupaten/kota di Jatim yaitu Sampang,
Ngawi, pamekasan, Trenggalek, Bondowoso, Situbondo, Jember dan Kediri.

Jumlah kematian ibu di Provinsi Jawa Timur mengalami penurunan yang cukup bermakna dari 642 kematian (2013) menjadi 291 kematian (2014). Penyebab terbanyak kematian ibu hamil adalah preeklamsia dan sebagian besar juga diakibatkan keterlambatan pengambilan keputusan keluarga untuk membawa ibu hamil beresiko tinggi ke pusat rujukan. Ada 3 keterlambatan yang menjadi penyebab ibu hamil beresiko tidak tertolong,yaitu: keluarga terlambat mengambil keputusan, terlambat sampai di tempat rujukan, dan terlambat mendapat penanganan (Kemenkes, 2009).

Tahun 2014 di Kabupaten Kediri terdapat 17 kematian ibu, penyebab terbesar kematian ibu adalah penyebab tidak langsung sebesar $41 \%$ kemudian Pre Eklamsia atau Eklamsia 24\%, perdarahan $18 \%$ dan infeksi $17 \%$ dan tahun 2015 sudah ditemukan 7 kematian ibu (Januari-April) penyebabnya adalah Eklamsia ( 1 orang), Preeklamsi Berat (1 orang), perdarahan post partum (2 orang), penyakit jantung ( 2 orang) dan kanker gastrointestinal (1 orang). Sedangkan kematian bayi pada tahun 2014 berjumlah 203 kasus, penyebab terbesarnya adalah asfiksia (50 kasus).

Usaha mempercepat keberhasilan penurunan Angka Kematian Ibu (AKI) dan Angka Kematian Bayi (AKB) disamping faktor akses dan pelayanan, peran serta lintas sektor khususnya yang terkait dengan upaya kesehatan ibu adalah meningkatkan kemitraan lintas sektor yang dituangkan dalam suatu kegiatan pendampingan ibu hamil resiko tinggi oleh kader yang dilaksanakan di kabupaten Kediri yang dikenal dengan program GEBRAK (Gerakan Amankan Kehamilan dan Persalinan.(Dinas Kesehatan Kab.Kediri, 2014)

Berdasarkan data Dinas Kesehatan Kabupaten Kediri tahun 2014 ibu hamil berjumlah 28.187 orang sedangkan ibu 
hamil resiko tinggi berjumlah 5637 orang (20\%). Jumlah ibu hamil resiko tinggi terbanyak di wilayah Puskesmas Blabak sejumlah 249 orang dengan jumlah kader 110 orang. Cakupan K1 96,2\% (100\%), Cakupan K4 92\% (95\%), Deteksi risiko tinggi oleh masyarakat $13,77 \%$ (20\%), Bumil Risti yang ditangani nakes $18,7 \%$ (20\%), Komplikasi kebidanan yang ditangani $87 \%$ (80\%), Persalinan oleh nakes difasilitas kesehatan $93 \%$ (95\%)

Berdasarkan penelitian Nani Khomsah berjudul Faktor-faktor yang berhubungan dengan peran serta kader posyandu dalam deteksi faktor risiko ibu hamil di wilayah kerja Puskesmas Buayan Kebumen Jawa Tengah (2012) dengan hasil analisis untuk motivasi tinggi nilai OR 5,6 pengetahuan baik OR 2,2, sikap positif OR 2,8 ,imbalan OR 3 sehingga dapat disimpulkan bahwa kader yang memiliki motivasi tinggi mempunyai peluang 6 kali untuk lebih berperan serta aktif dalam deteksi faktor resiko antenatal (Khomsah, 2012)

Pemberian penghargaan dan motivasi kepada kader posyandu sangatlah penting, khususnya kader pendamping ibu hamil risti. Dalam program GEBRAK penghargaan diharapkan semakin memacu para kader untuk ikut bekerja sosial demi menekan AKI, sehingga kader bisa meningkat setiap tahunnya.

Berdasarkan latar belakang diatas peneliti tertarik untuk melakukan penelitian mengenai Pengaruh Motivasi Internal Dan Eksternal Terhadap Kinerja Kader Dalam Program Gebrak ( Gerakan Bersama Amankan Kehamilan Dan Persalinan) Di Wilayah Puskesmas Blabak Kabupaten Kediri

\section{METODE PENELITIAN}

Desain yang digunakan dalam penelitian ini adalah penelitian survei. Ditinjau dari sifatnya survei ini merupakan explanotory survey yaitu survei yang menguji kebenaran suatu hipotesis dengan menjelaskan hubungan sebab akibat antar variabel. Populasi terjangkau pada penelitian ini semua kader pendamping ibu hamil resiko tinggi di wilayah Puskesmas Blabak Kabupaten Kediri pada tahun 2014 sebanyak 66. Besar sampel dalam penelitian ini menggunakan rumus sebagai berikut:

$$
\begin{aligned}
& \mathrm{n}=\mathrm{N} / \mathrm{N}(\mathrm{d})^{2}+1 \\
& \mathrm{n}=66 / 66(0,05)^{2}+1=56
\end{aligned}
$$

\section{dibulatkan menjadi 57}

Tehnik sampling yang digunakan teknik simple random sampling. Variabel yang diteliti dalam penelitian ini adalah sebagai berikut:

1. Variabel bebas/eksogen $(\mathrm{X})$ :

$\mathrm{X} 1$ : Motivasi internal

X2: Motivasi external

2. 2.Variabel terikat/endogen $(\mathrm{Y})$ :

Y1: kinerja kader dalam Program GEBRAK.

Instrumen pengumpulan data menggunakan kuesioner yang diisi langsung oleh responden setelah diberi penjelasan oleh peneliti tentang cara pengisian.Jenis pertanyaan kuesioner adalah kuesioner tertutup. Analisa data dalam penelitian ini menggunakan program Smart PLS Pemodelan persamaan structural yang sering disebut dengan Structural EquationModeling ( SEM) atau Linear Structural Relationship (LISREL). 
HASIL PENELITIAN

\section{Karakteristik Responden}

Tabel 1 Karakteristik responden

\begin{tabular}{|c|c|c|c|}
\hline No & $\begin{array}{l}\text { Karakteristik } \\
\text { Responden }\end{array}$ & Frekuensi & Persentase \\
\hline \multirow[t]{4}{*}{1} & Usia & & \\
\hline & $\begin{array}{ll}- & 20-30 \\
& \text { tahun }\end{array}$ & 1 & 1,8 \\
\hline & $\begin{array}{ll}- & 31-40 \\
& \text { tahun }\end{array}$ & 24 & 42,1 \\
\hline & $\begin{array}{l}-\quad 41-50 \\
\text { tahun }\end{array}$ & 32 & 56,1 \\
\hline \multirow[t]{6}{*}{2} & Tingkat & & \\
\hline & Pendidikan & & \\
\hline & $-\quad \mathrm{SD}$ & 2 & 3,5 \\
\hline & - $\quad$ SMP & 16 & 28,1 \\
\hline & - $\quad$ SMA & 32 & 56,1 \\
\hline & - $\quad$ PT & 7 & 12,3 \\
\hline \multirow[t]{7}{*}{3} & Lama menjadi & & \\
\hline & Kader & & \\
\hline & $-\quad 1-5$ & 13 & 22,8 \\
\hline & $-6-10$ & 8 & 14 \\
\hline & $-\quad 11-15$ & 19 & 33,3 \\
\hline & $-\quad 16-20$ & 8 & 14 \\
\hline & $-\quad 21-25$ & 9 & 15,8 \\
\hline
\end{tabular}

Berdasarkan tabel diatas responden sebagian besar $(56,1 \%)$ berusia $41-50$ tahun, tingkat pendidikan sebagian besar $(56,1 \%)$ berpendidikan SMA, sedangkan lama menjadi kader $(33,3 \%)$ berkisar antara 11-15 tahun.

Tabel 2 Hasil Uji Validitas

\begin{tabular}{|c|c|c|c|c|c|c|}
\hline & abel & Loading $(\lambda)$ & $\begin{array}{c}\text { Rata-rata } \\
\text { Sub } \\
\text { Sampel }\end{array}$ & $\begin{array}{c}\text { Standart } \\
\text { error }\end{array}$ & $\begin{array}{c}\text { T- } \\
\text { Statistik }\end{array}$ & keterangan \\
\hline \multirow{4}{*}{$\begin{array}{l}\text { Motivasi } \\
\text { Internal }\end{array}$} & $\begin{array}{l}\text { Aktualisasi } \\
\text { Diri }\end{array}$ & 0,832 & 0.666 & 0,445 & 1,866 & Valid \\
\hline & Penghargaan & 0,759 & 0.622 & 0,381 & 1,993 & $\begin{array}{l}\text { Valid dan } \\
\text { signifikan }\end{array}$ \\
\hline & $\begin{array}{l}\text { Tanggung } \\
\text { Jawab }\end{array}$ & 0,652 & 0.492 & 0,330 & 1,974 & $\begin{array}{l}\text { Valid dan } \\
\text { signifikan }\end{array}$ \\
\hline & Prestasi & 0,826 & 0.650 & 0,446 & 1,849 & Valid \\
\hline \multirow{3}{*}{$\begin{array}{l}\text { Motivasi } \\
\text { Eksternal }\end{array}$} & Gaji/Upah & 0,924 & 0.852 & 0,282 & 3,267 & $\begin{array}{l}\text { Valid dan } \\
\text { signifikan }\end{array}$ \\
\hline & $\begin{array}{l}\text { Hubungan } \\
\text { Sosial }\end{array}$ & 0,818 & 0.761 & 0,248 & 3,296 & $\begin{array}{l}\text { Valid dan } \\
\text { signifikan }\end{array}$ \\
\hline & Lingkungan & 0,848 & 0.771 & 0,327 & 2,587 & $\begin{array}{l}\text { Valid dan } \\
\text { signifikan }\end{array}$ \\
\hline \multirow{3}{*}{ Kinerja } & Hasil Kerja & 0,911 & 0.802 & 0,264 & 3,443 & $\begin{array}{l}\text { Valid dan } \\
\text { signifikan }\end{array}$ \\
\hline & $\begin{array}{l}\text { Perilaku } \\
\text { Kerja }\end{array}$ & 0,855 & 0.777 & 0,242 & 3,524 & $\begin{array}{l}\text { Valid dan } \\
\text { signifikan }\end{array}$ \\
\hline & Sifat Pribadi & 0,316 & 0.324 & 0,437 & 0,724 & $\begin{array}{c}\text { Tidak Valid } \\
\text { dan Tidak } \\
\text { Signifikan }\end{array}$ \\
\hline
\end{tabular}

Sumber : Data Olahan SmartPLS 
Berdasarkan tabel diatas dapat disimpulkan bahwa nilai loading dari hubungan variabel indikator Penghargaan dan Tanggung Jawab dengan konstruk Motivasi internal, hubungan variabel indikator Gaji/Upah, Hubungan Sosial dan Lingkungan dengan konstruk Motivasi Eksternal, hubungan variabel indikator Hasil Kerja dan Perilaku Kerja dengan konstruk Kinerja, masing-masing memiliki nilai loading ${ }^{(\lambda)} \geq 0.5$, dan memiliki nilai T-statistik > 1.96 pada taraf signifikansi ${ }^{\alpha}=0,05$..

Dengan demikian variabel indikator Penghargaan dan Tanggung Jawab dapat dikatakan valid untuk mengukur konstruk Motivasi Internal, sedangkan variabel indikator Gaji/Upah, Hubungan Sosial dan Lingkungan dapat dikatakan valid untuk mengukur konstruk Motivasi Eksternal, variabel indikator Hasil Kerja dan Perilaku Kerja dapat dikatakan valid untuk mengukur konstruk Kinerja.

\section{Uji Reliabilitas :}

Dalam penelitian ini suatu variabel dikatakan cukup reliabilitas bila variabel tersebut mempunyai nilai construc reliability lebih besar dari 0,6. Berikut adalah hasil pengujian reabilitas pada masing-masing variabel laten dengan bantuan software SmartPLS.

Tabel 3 Pengujian Reliabilitas

\begin{tabular}{lccc}
\hline \multicolumn{1}{c}{ Variabel } & AVE & $\begin{array}{c}\text { Reliabilitas } \\
\text { Komposit }\end{array}$ & Keterangan \\
\hline Kinerja & 0.554637 & 0,764 & Reliabel \\
Motivasi & 0.747864 & 0,898 & Reliabel \\
Eksternal & 0.594431 & 0,853 & Reliabel \\
Motivasi Internal & & & \\
\hline
\end{tabular}

Berdasarkan hasil tabel diatas, dapat bahwa indikator-indikator yang digunakan yaitu pada variabel (Penghargaan, Tanggung Jawab, Gaji/Upah, Hubungan Sosial, Lingkungan,Hasil Kerja, dan Perilaku Kerja) mempunyai reabilitas yang cukup baik atau mampu untuk mengukur konstruknya. 0.7 begitu juga dengan variabel laten endogen Kinerja memiliki nilai AVE > 0.5 dan $\rho_{c} \geq 0.7$ maka dapat disimpulkan

Tabel 4. Hasil Pengujian Indikator Model

\begin{tabular}{|c|c|c|c|c|c|c|}
\hline & iabel & $\operatorname{Loading}(\lambda)$ & $\begin{array}{c}\text { Rata-rata } \\
\text { Sub }\end{array}$ & $\begin{array}{c}\text { Standart } \\
\text { error }\end{array}$ & $\begin{array}{c}\mathrm{T}- \\
\text { Statistik }\end{array}$ & keterangan \\
\hline & Penghargaan & 0.867 & 0.720 & 0.376 & 2.302 & signifikan \\
\hline Internal & $\begin{array}{l}\text { Tanggung } \\
\text { Jawab }\end{array}$ & 0.759 & 0.666 & 0.351 & 2.160 & signifikan \\
\hline & Gaji/Upah & 0.925 & 0.917 & 0.047 & 19.352 & signifikan \\
\hline $\begin{array}{l}\text { Motivasi } \\
\text { Eksternal }\end{array}$ & $\begin{array}{l}\text { Hubungan } \\
\text { Sosial }\end{array}$ & 0.812 & 0.792 & 0.094 & 8.619 & signifikan \\
\hline & Lingkungan & 0.855 & 0.854 & 0.079 & 10.816 & signifikan \\
\hline & Hasil Kerja & 0.918 & 0.911 & 0.084 & 10.887 & signifikan \\
\hline Kinerja & $\begin{array}{l}\text { Perilaku } \\
\text { Kerja }\end{array}$ & 0.854 & 0.804 & 0.197 & 4.319 & signifikan \\
\hline
\end{tabular}

Sumber : Data Olahan SmartPLS 
Dari tabel diatas semua indikator memiliki nilai T-statistik > 1.96 pada taraf signifikansi ${ }^{\alpha}=0,05$ yang berarti semua indicator dapat digunakan untuk mengukur konstruknya. Indikator yang mempunyai pengaruh terbesar terhadap motivasi internal adalah penghargaan. Indikator yang memiliki pengaruh paling besar terhadap motivasi eksternal adalah gaji/upah. Indikator yang memiliki pengaruh paling besar terhadap kinerja adalah hasil kerja.

\section{Evaluasi Model Struktural}

\section{Tabel 5. Hasil Pengujian Hubungan}

Kausalitas Model Struktural

\begin{tabular}{lccc}
\hline $\begin{array}{l}\text { Hubungan } \\
\text { Kausalitas }\end{array}$ & $\begin{array}{l}\text { Koefisien } \\
\text { Parameter }\end{array}$ & $\begin{array}{l}\text { Standart } \\
\text { error }\end{array}$ & $\begin{array}{l}\text { T- } \\
\text { statistik }\end{array}$ \\
\hline $\begin{array}{l}\text { Motivasi } \\
\text { Eksternal - } \\
>\text { Kinerja }\end{array}$ & 0.347 & 0.128 & 2.708 \\
\hline $\begin{array}{l}\text { Motivasi } \\
\text { Internal -> } \\
\text { Kinerja }\end{array}$ & -0.120 & 0.117 & 1.023 \\
\hline
\end{tabular}

Pengaruh hubungan variabel laten eksogen terhadap variabel laten endogen (derajat kesehatan) pada tabel diatas dapat dijelaskan sebagai berikut :

1. Koefisien parameter jalur yang diperoleh dari hubungan antara variabel Motivasi Eksternal dengan Kinerja sebesar 0.347 dengan nilai Tstatistik $2,708>1,96$ pada taraf signifikansi $\alpha=0,05$ (5\%) yang menyatakan bahwa terdapat pengaruh yang signifikan antara Motivasi Eksternal dengan Kinerja. Nilai positif pada koefisien parameter artinya adalah semakin baik motivasi eksternal maka kinerja akan semakin baik pula.

2. Koefisien parameter jalur yang diperoleh dari hubungan antara variabel motivasi internal dengan kinerja sebesar -0.120 dengan nilai T-statistik $1,023<1,96$ pada taraf signifikansi $\alpha=0,05$ (5\%) yang menyatakan bahwa tidak terdapat pengaruh yang signifikan antara motivasi internal dengan kinerja.
Berdasarkan koefisien - koefisien parameter jalur yang diperoleh pada tabel 3.3 maka model persamaan struktural yang terbentuk adalah sebagai berikut :

Kinerja = 0.347 Motivasi Eksternal

\section{PEMBAHASAN}

Pengukuran pengaruh motivasi internal dan eksternal terhadap kinerja kader dalam program GEBRAK

\section{1) Motivasi Internal}

Motivasi intrinsik adalah faktor yang mendorong seserang termotivasi, yaitu daya dorong yang timbul dari dalam diri masing-masing orang. Hasil penelitian menunjukkan indikator yang menyusun motivasi internal meliputi aktualisasi diri, penghargaan, tanggung jawab, prestasi. Dari ke empat indikator tersebut yang secara signifikan menyusun motivasi internal adalah indikator penghargaan dan tanggung jawab.

\section{(1) Aktualisasi diri}

Aktualisasi diri adalah suatu kebutuhan mengungkapkan diri yaitu merupakan kebutuhan manusia yang paling tinggi dalam teori Maslow. Kebutuhan ini akan muncul apabila kebutuhan-kebutuhan yang ada di bawahnya telah terpuaskan dengan baik. Kebutuhan aktualisasi ditandai sebagai hasrat individu untuk menjadi orang yang sesuai dengan keingiman dan potensi yang dimilikinya, atau hasrat dari individu untuk menyempurnakan dirinya melalui pengungkapan segenap potensi yang dimilikinya.

Aktualisasi diri bisa berupa penciptaan kreasi atau karya-karya berdasarkan bakat atau kemampuan khusus, semua orang bisa mengaktualisasikan dirinya yakni dengan jalan membuat yang terbaik atau bekerja sebaik-baiknya sesuai dengan bidang masing-masing. Setiap individu berbeda beda bentuk aktualisasi dirinya dikarenakan adanya perbedaan-perbedaan individual. (Robbins.2003).

Aktualisasi diri yang dimiliki kader di wilayah Puskesmas Blabak sudah 
menunjukkan hasil yang baik. Misalnya sebagian besar kader sudah percaya diri tampil memberikan penyuluhan tanda bahayagizi dan perawatan ibu hamil.

\section{(2) Penghargaan}

Berdasarkan hasil penelitian indikator penghargaan secara nyata sangat mempengaruhi motivasi internal seseorang. Sistem penghargaan dapat berkontribusi memuaskan orang, memenuhi keinginan, memberi pembelajaran dan meningkatkan kemapuan seseorang (Roberts,2005). Kader di wilayah Puskesmas Blabak telah diberikan penghargaan berkaitan dengan keterlibatannya dalam program GEBRAK misalnya adanya penggantian biaya transport dan pelatihan secara berkala deteksi dini ibu hamil resiko tinggi. Penghargaan ini mampu membuat kader lebih bersemangat dalam bekerja terutama dalam menggerakkan ibu hamil, bersalin dan nifas untuk memeriksakan kesehatannya di tenaga kesehatan.

\section{(3) Prestasi}

Hasil penelitian menunjukkan bahwa indikator prestasi mampu mengukur motivasi internal walaupun tidak signifikan. Kebutuhan untuk berprestasi yang merupakan refleksi dari dorongan akan tanggung jawab untuk pemecahan masalah. Seseorang yang mempunyai kebutuhan akan prestasi yang tinggi cenderung untuk berani mengambil risiko. Kebutuhan untuk berprestasi adalah kebutuhan untuk melakukan pekerjaan lebih baik dari sebelumnya, selalu berkeinginan mencapai prestasi yang lebih tinggi.

Menurut Mc Clelland pengertian motivasi berprestasi didefinisikan sebagai usaha mencapai sukses atau berhasil dalam kompetisi dengan suatu ukuran keunggulan yang dapat berupa prestasi orang lain maupun prestasi sendiri. Lindgren mengemukakan hal senada bahwa motivasi berprestasi sebagai suatu dorongan yang ada pada seseorang sehubungan dengan prestasi, yaitu menguasai, memanipulasi serat mengatur lingungan sosial maupun fisik, mengatasi segala rintangan dan memelihara kualitas kerja yang tinggi, bersaing melalui usahausaha untuk melebihi hasil kerja yang lampau, serta mengungguli hasil kerja yang lain.(Robbins, 2013)

Senada dengan pendapat di atas, Santrork menjelaskan bahwa motivasi berprestasi merupakan keinginan untuk menyelesaikan sesuatu untuk mencapai suatu standar kesuksesan, dan untuk melakukan suatu usaha dengan tujuan untuk mencapai kesuksesan. Gagne dan Barliner menambahkan bahwa motivasi berprestasi adalah cara seseorang untuk berusaha dengan baik untuk prestasinya.

Menurut Heckhausen motif berprestasi diartikan sebagai usaha untuk meningkatkan atau melakukan kecakapan pribadi setinggi mungkin dalam segala aktivitas dan suatu ukuran keunggulan tersebut digunakan sebagai pembanding, meskipun dalam usaha melakukan aktivitas tersebut ada duakemungkinan yakni gagal atau berhasil. Selanjutnya ia menjelaskan bahwa motivasi berprestasi merupakan motif yang mendorong individu untuk mencapai sukses dan bertujuan untuk berhasil dalam kompetisi dengan beberapa ukuran keunggulan (standard of excellence). Ukuran keunggulan digunakan untuk standar keunggulan prestasi dicapai sendiri sebelumnya dan layak seperti dalam suatu kompetisi.

Dalam teori expectancy-value Atkinson mengemukakan bahwa motivasi berprestasi seseorang didasarkan atas dua hal yaitu, adanya tendensi untuk meraih sukses dan adanya tendensi untuk menghindari kegagalan. Pada dasarnya keadaan motif itu dimiliki oleh individu, namun keduanya mempunyai keadaan berbeda-beda dalam berbagai situasi dan kondisi menurut adanya prestasi. Lebih jelasnya Atkinson mengemukakan bahwa keberhasilan individu untuk mencapai kebehasilan dan memenangkan persaingan 
berdasarkan standar keunggulan, sangat terkait dengan tipe kepribadian yang memiliki motif berprestasi lebih tinggi daripada motif untuk menghindari kegagalan begitu pula sebaliknya, apabila motif menghindari terjadinya kegagalan lebih tinggi daripada motif sukses, maka motivasi berprestasi seseorang cenderung rendah. Dari uraian tersebut dapat disimpulkan bahwa motivasi berprestasi atau achievement motivation merupakan suatu dorongan yang berhubungan dengan bagaimana melakukan sesuatu dengan lebih baik, lebih cepat, lebih efisien dibandingkan dengan apa yang telah dilakukan sebelumnya, sebagai usaha mencapai sukses atau berhasil dalam kompetisi dengan suatu ukuran keunggulan yang dapat berupa prestasi orang lain maupun prestasi sendiri.

McClelland mengemukakan bahwa ada 6 karakteristik individu yang mempunyai motivasi berprestasi yang tinggi, yaitu :

1) Perasaan yang kuat untuk mencapai tujuan, yaitu keinginan untuk menyelesaikan tugas dengan hasil yang sebaik-baiknya.

2) Bertangungjawab, yaitu mampu bertanggungjawab terhadap dirinya sendiri dan menentukan masa depannya, sehingga apa yang dicitacitakan berhasil tercapai.

3) Evaluatif, yaitu menggunakan umpan balik untuk menentukan tindakan yang lebih efektif guna mencapai prestasi, kegagalan yang dialami tidak membuatnya putus asa, melainkan sebagai pelajaran untuk berhasil.

4) Mengambil resiko "sedang", dalam arti tindakan-tindakannya sesuai dengan batas kemampuan yang dimilikinya.

5) Kreatif dan inovatif, yaitu mampu mencari peluang-peluang dan menggunakan kesempatan untuk dapat menunjukkan potensinya.

6) Menyukai tantangan, yaitu senang akan kegiatan-kegiatan yang bersifat prestatif dan kompetitif.(Robbins)
Kader di wialyah Puskesmas Blabak sudah menunjukkan prestasi yang baik, hal ini ditunjukkan dengan penyampaian informasi ke tenaga kesehatan hasil melakukan kunjungan rumah yang tepat waktu, pencatatan dan pelaporan persalinan dan BBL yang rutin ke tenaga kesehatan.

\section{(4) Tanggung jawab}

Tanggung jawab merupakan salah satu komponen motivasi internal yang sangat penting, hasil penelitian menunjukkan indikator tanggung jawab secara nyata mampu mengukur motivasi internal. Pengertian tanggung jawab dalam Kamus Umum Bahasa Besar Indonesia adalah keadaan dimana wajib menanggung segala sesuatu, sehingga berkewajiban menanggung menanggung segala sesuatunya dan menanggung akibatnya.

Tanggung jawab adalah ciri manusia beradab (berbudaya). Manusia merasa bertanggung jawab karena ia menyadari akibat baik atau buruk perbuatannyaitu, dan menyadari pula bahwa pihak lain memerlukan pengabdian atau pengorbanannya. Untuk memperoleh atau meningkatkan kesadaran bertanggung jawab perlu ditempuh usaha melalui pendidikan, penyuluhan, keteladanan dan takwa kepada Tuhan Yang Maha Esa.

Pada hakekatnya manusia tidak bisa hidup tanpa bantuan manusia lain, sesuai dengan kedudukannya sebagai mahluk sosial. Karena membutuhkan manusia lain maka ia harus berkomunikasi dengan manusia lain. Sehingga dengan demikian manusia disini merupakan anggota masyarakat yang tentunya mempunyai tanggung jawab seperti anggota masyarakat yang lain agar dapat melangsungkan hidupnya dalam masyrakat tersebut. Wajarlah apabila segala tingkah laku dan perbuatannya harus dipertanggung jawabkan kepada masyarakat.

Kader di wialyah Puskesmas Blabak sudah menunjukkan tanggung jawab seorang kader dalam melaksanakan 
tugasnya yang didasari sikap ikhlas dan sukarela. Kader bertanggung jawab dalam pendampingan ibu hamil resiko tinggi sampai dengan masa nifas.dalam hal memotivasi bumil agar periksa secara rutin bila perlu diantar, memotivasi persalinan ke petugas kesehatan dan difasilitas kesehatan, memotivasi ibu untuk melakukan pelayanan masa nifas dan bayi baru lahir ke tenaga kesehatan.

\section{2) Motivasi Eksternal}

(1) Gaji/Insentif

Hasil penelitian menunjukkan indikator gaji/upah memiliki pengaruh yang paling besar dalam mengukur motivasi eksternal dibandingkan indikator hubungan sosial dan lingkungan. Insentif merupakan daya tarik yang menyebabkan seseorang melakukan sesuatu karena biasa mendapatkan imbalan yang memuaskan kebutuhannya. Apabila insentif tersebut sesuai dengan motiv yang ada, maka individu akan tertarik untuk memanfaatkan insentif tersebut. Sebaliknya apabila insentif tersebut tidak sesuai dengan motiv yang ada maka insentif yang ditawarkan hanya sedikit menarik perhatian.

Apabila insentif tersebut nampaknya bisa memuaskan motiv yang ada, maka individu itu mulai mempertimbangkan nilai insentif sebagai alat untuk memuaskan dorongan dalam dirinya. Pertimbangan pada fase ini terpusat pada tingkat kepuasan yang akan diperoleh apabila usaha ditingkatkan menjadi pelaksanaan apabila pelaksanaan tersebut berhasil dan apabila imbalan yang dijanjikan oleh insentif diterima.

Gaji atau insentif kaitannya dengan stimuli atau penghargaan eksternal dan merupakan stimulus eksternal dianggap menarik seseorang untuk beberapa tujuan. Teori ini mengatakan bahwa seseorang akan bergerak atau mengambil tindakan karena ada insentif yang akan di dapatkan. Misalnya, seseorang mau bekerja dari pagi sampai sore karena tahu bahwa ia akan mendapatkan intensif berupa gaji, jika seseorang tahu akan mendapatkan penghargaan, maka ia pun akan bekerja lebih giat lagi dalam bekerja.

Kebutuhan akan adanya insentif dapat berupa banyak alasan, tujuan pemberian insentif antara lain:

1. Untuk meningkatkan produktifitas,

2. Untuk mendorong atau membangkitkan stimulus kerja,

3. Untuk meningkatkan komitmen dalam prestasi kerja,

4. Untuk secara psikologis memuaskan seseorang yang mengarah ke kepuasan kerja,

5. Untuk membentuk perilaku atau pandangan dari bawahan tentang pekerjaan,

6. Untuk menanamkan semangat dan antusiasme terhadap pekerjaan, Untuk mendapatkan hasil maksimal dari kemampuan seseorang sehingga orang tersebut dapat dimanfaatkan secara maksimal.

Gaji atau insentif yang diterima kader dalam program GEBRAK tidak besar tetapi sangat mempengaruhi motivasi kader. Kader bersifat sukarela ,ketika mendapatkan insentif tambahan mampu meningkatkan motivasinya.

\section{(2) Lingkungan}

Hasil penelitian menunjukkan indikator lingkungan dapat digunakan untuk mengukur motivasi eksternal. Lingkungan kerja mempuyai pengaruh langsung terhadap seseorang yang melaksanakan tugasnya. Lingkungan kerja yang nyaman dapat meningkatkan kinerja. Sebaliknya, lingkungan kerja yang tidak memadai akan dapat menurunkan kinerja. Kinerja dikatakan baik atau sesuai apabila manusia dapat melaksanakan kegiatan secara optimal, sehat, aman dan nyaman.

Lingkungan kerja merupakan segala sesuatu yang ada disekitar para pekerja yang dapat mempengaruhi dirinya dalam menjalankan tugas-tugas yang diembannya. (Halim HS:2012) 
Kader merasakan kondisi lingkungan yang sehat, aman dan nyaman saat bekerja di posyandu, melakukan kunjungan rumah, dan di Puskesmas. Hal ini didukung juga lingkungan kerja non fisik seperti rasa saling menghargai, kerjasama dan saling tolong-menolong menjadikan kader lebih bersemangat dalam melaksanakan tugas.

\section{(3) Hubungan sosial}

Berdasarkan hasil penelitian indikator terakhir yang dapat digunkan untuk mengukur motivasi eksternal adalah indikator hubungan sosial. Kebutuhan akan Afiliasi adalah hasrat untuk berhubungan antar pribadi yang ramah dan akrab. Individu merefleksikan keinginan untuk mempunyai hubungan yang erat, kooperatif dan penuh sikap persahabatan dengan pihak lain. Individu yang mempunyai kebutuhan afiliasi yang tinggi umumnya berhasil dalam pekerjaan yang memerlukan interaksi sosial yang tinggi.

McClelland mengatakan bahwa kebanyakan orang memiliki kombinasi karakteristik tersebut, akibatnya akan mempengaruhi perilaku karyawan dalam bekerja atau mengelola organisasi. Kebutuhan untuk berafiliasi yang merupakan dorongan untuk berinteraksi dengan orang lain, berada bersama orang lain, tidak mau melakukan sesuatu yang merugikan orang lain.

Hubungan sosial yang dijalin oleh kader ketika berinteraksi dengan ibu hamil dengan ramah dan akrab misalnya mendampingi ibu hamil dalam memahami isi buku KIA dan memotivasi KB setelah melahirkan. Hubungan sosial juga dibentuk melalui dukungan dari masyarakat misalnya hadir dalam acara pengajian dan arisan.

\section{3) Kinerja}

(1) Hasil kerja

Hasil penelitian menunjukkan bahwa indikator hasil kerja merupakan indikator yang memiliki pengaruh paling besar dalam pengukuran kinerja. Hasil kerja dapat dilihat dari pencapaian tujuan pekerjaan. Hasil kerja kader ditunjukkan dengan melaksanakan tugas secara tepat sesuai prosedur yang ditetapkan, memuaskan sesuai target yang ditetapkan dan berkualitas.

\section{(4) Perilaku kerja}

Hasil penelitian menunjukkan indikator perilaku kerja dapat digunakan untuk mengukur kinerja seseorang. Perilaku kerja merupakan perilaku seseorang yang berhubungan dengan pekerjaan dan tidak ada hubungan dengan pekerjaan . Perilaku kader yang tidak berhubungan dengan pekerjaan yaitu cara berbicara dan cara berjalan. Perilaku kader yang berhubungan dengan pekerjaan yaitu kerja keras dan ramah terhadap masyarakat khususnya pada ibu hamil.

Perilaku kerja kader terhadap pelaksanaan program GEBRAK memerlukan kerjasama baik dengan kader yang lain, bidan, Kepala Puskesmas dan masyarakat. Kader didesa tetap bekerja dengan baik walaupun bidan desa tidak ada ditempat. Sebagian besar kader telah bekerja selama 11- 15 tahun memberikan pengalaman kader mengenal lebih dekat dengan karakteristik masyarakat khususnya ibu hamil, bersalin dan nifas.

\section{Menganalisis faktor motivasi yang mempunyai pengaruh terhadap kinerja}

Hasil penelitian menunjukkan motivasi eksternal berpengaruh terhadap kinerja sedangkan motivasi internal tidak berpengaruh terhadap kinerja. Hal ini sesuai dengan teori evaluasi kognitif bahwa motivasi eksternal yang kuat diberikan kepada seseorang untuk menjalankan suatu tugas menyebabkan motivasi intrinsik terhadap tugas itu sendiri merosot.

Hal ini berbeda dengan Herzberg bahwa faktor hygienis/extrinsic factor tidak akan mendorong minat para pegawai untuk berforma baik, akan tetapi jika 
faktor-faktor ini dianggap tidak dapat memuaskan dalam berbagai hal seperti gaji tidak memadai, kondisi kerja tidak menyenangkan, faktor-faktor itu dapat menjadi sumber ketidakpuasan potensial. (Robbins, 2003)

Kader di wilayah Puskesmas Blabak memiliki dorongan dari luar lebih besar sehingga dorongan dari dalam menjadi lemah tetapi hal ini tidak mengurangi motivasi internal, kader tetap termotivasi sesuai dengan tugas dan tanggung jawabnya

\section{KESIMPULAN}

1. Tidak Ada pengaruh motivasi internal terhadap kinerja kader dalam program GEBRAK (Gerakan Bersama Amankan Kehamilan Dan Persalinan).

2. Ada pengaruh motivasi external terhadap kinerja kader dalam program GEBRAK (Gerakan Bersama Amankan Kehamilan Dan Persalinan).

3. Motivasi eksternal memiliki pengaruh terbesar terhadap kinerja kader dalam program GEBRAK (Gerakan Bersama Amankan Kehamilan Dan Persalinan).

\section{SARAN}

1. Kader diharapkan mempertahankan motivasi dalam mendampingi ibu hamil resiko tinggi

2. Kepala Puskesmas dan Bidan diharapkan memberikan motivasi kepada kader dalam mendampingi ibu hamil resiko tinggi secara berkesinambungan

3. Dinas kesehatan dan desa diharapkan memberikan tambahan insentif bagi kader pendamping ibu hamil resiko tinggi

\section{DAFTAR PUSTAKA}

Adriaansz G. Periode kritis rentang kehamilan, persalinan, nifas dan penyediaan berbagai jenjang pelayanan bagi upaya penurunan kematian ibu, bayi dan anak. Health Service Program- USAID ; 2005.

Dahlan MS. Besar Sampel dan cara pengambilan sampel dalam penelitian kedokteran dan kesehatan. Edisi ke-3. Jakarta Salemba Medika;2010

Dinas Kesehatan Kabupaten Kediri, Data PWSKIA 2014

Hasibuan M. Managemen sumber daya manusia.Edisi ke 11.Jakarta: Bumi Aksara; 2010

Halim HS. Analisis pengaruh motivasi dan lingkungan kerja terhadap kinerja karyawan pada PT Sinar Galesong Pratama Makasar.Skripsi. UNHAS Makasar.2012.

Kemenkes RI. Program Perencanaan persalinan dan pencegahan komplikasi (P4K) dengan stiker. Jakarta;2009.

Kemenkes RI. Rencana operasional promosi kesehatan ibu dan anak. Jakarta .2010

Kemenkes RI. Rencana strategis kementerian kesehatan 2010-2014. Jakarta 2010

Khomsah Nani, Faktor-faktor yang berhubungan dengan peran serta kader posyandu dalam deteksi faktor risiko ibu hamil di wilayah kerja Puskesmas Buayan Kebumen Jawa Tengah, Skripsi Fakultas Kesehatan Masyarakat UI. 2012.

Kusnendi. Model-model persamaan struktural. Edisi ke-1. Bandung: Alfabetha; 2008.

Mangkunegara AP, Evaluasi kinerja SDM. Bandung: Refia Aditam; 2010

Notoadmodjo S. Promosi Kesehatan dan aplikasinya. Jakarta: Rineka Cipta: 2005

Riduwan, Kuncoro AE. Cara menggunakan dan memakai path analysis. Edisi ke-3. Bandung: Alfabeta:2011

Rivai V,Sagala EJ.Manajemen Sumber Daya Manusia untuk Perusahaan. Rajawali Pers.Jakarta.2013 
Ghozali, I. Struktural Equation Modeling Metode Alternatif dengan Partial Least Square (PLS), Universitas Diponegoro, Semarang, 2006

Rochyati Poedji, Skrining Antenatal Pada Ibu Hamil, Pengenalan Faktor Risiko Deteksi Dini Ibu Hamil Risiko Tinggi, Cetakan-1, Airlangga University Press, Surabaya, 2003.

Robbins SP. Perilaku organisasi. 9 ed. Jakarta: PT Indeks Kelompok Gramedia; 2003.

Siagian SP., Teori Motivasi dan Aplikasinya. Jakarta. Rineka Cipta, 2004

Simamora H. Managemen sumber daya manusia. Edisi ke-3. Yogyakarta: STIE YKPN;2006.

Sugiyono, Statistik Untuk Penelitian dan Aplikasinya, Alfabeta, Bandung, 2006

Sudjana. Metode Statistika. Tarsito, Bandung, 2002

Wijanto SH. Struktural equation modelling dengan LISREL 8,8 konsep dan tutorial. Edisi ke-1. Yogyakarta: Graha Ilmu;2008

Wirawan . Evaluasi kinerja sumber daya manusia, teori aplikasi dan penelitian. Jakarta: Salemba Empat; 2009.

Www.Manajemenstudyguide.com. 2011. Motivation Incentives Incentives to motivate 